\title{
Okul Öncesi Hışıltılı Çocuk Tedavisi ve İlemine Güncel Yaklaşım
}

\section{Current Approach to Treatment and Follow-Up of Pre-School Children with Wheezing}

Pınar Uysal, Özkan Karaman

Dokuz Eylül Üniversitesi Tıp Fakültesi, Çocuk Sağlığı ve Hastalıkları Anabilim Dalı, İmmunoloji ve Klinik Allerji Bilim Dalı, Izmir, Türkiye

Yazışma Adresi/Address for Correspondence Dr. PInar Uysal Dokuz Eylül Üniversitesi Tip Fakültesi, Çocuk Sağı̆ı̆ı ve Hastalılıarı Anabilim Dalı, Immunoloji ve Klinik Allerij Bilim Dal, Izmir, Türkiye $T e l \cdot+902324126062$ E-posta: druysal.pinar@gmail.com

Geliş Tarihi/Received: 08.09.2011 Kabul Tarihi/Accepted: 13.12.2011

(c) Güncel Pediatri Dergisi, Galenos Yayınevi tarafindan basılmıștır.

(c) The Journal of Current Pediatrics, published by Galenos Publishing.

\section{ÖZET}

Erken yaşta geçirilen hışıltı atakları ve havayolu hiperreaktivitesi daha sonra gelişebilecek astım açısından ilk bulgu olabilir. Bu nedenle bu hastalara uygulanacak tedavi yaklaşımı önemlidir. Tedavinin ilk ve en önemli basamağı primer korunma ve hastanın hastalığı hakkında eğitimidir. Epizodik (viral) ve çoklu-tetikleyicili hışıltının her ikisinde de atak tedavisinde ilk tercih edilmesi gereken ilaçlar $\beta_{2}$ agonistlerdir. Bronkodilatatörler akut hışıtı ataklarında semptomatik rahatlama sağlarlar iken, oral kortikosteroidlerin ataklardaki yeri tartışmalıdır. Atak tedavisinde ailelerin oral kortikosteroid başlamaları önerilmemektedir. İdame tedavisinde, epizodik (viral) hışıltıda düşük-orta doz inhale kortikosteroidlerin (IKS) devamlı kullanımı etkisizdir. Ancak, çoklu tetikleyicili hışılıda İKS'lerin yararlı etkileri bulunmaktadır. Çocuklarda yüksek doz inhale IKS'ler aralıklı kullanıldığında her iki hışıltı tipinde de etkili gibi görünmektedir. Fakat, kısa dönemde yüksek doz İKS'lerin büyüme üzerine olumsuz etkileri olması nedeni ile rutin olarak kullanımları önerilmemektedir. Lökotrien reseptör antagonistleri (LTRA) çoklu tetikleyicili çocuklarda önerilebilir. Antihistaminikler, ketotifen ve kromolinlerin hışıltılı çocuk tedavisinde yeri yoktur. (Güncel Pediatri 2012; 10: 98-102)

Anahtar kelimeler: Alevlenme, hışıltılı çocuk, tedavi

\section{SUMMARY}

Exacerbations of wheezing or airway hyperreactivity in early years of life might be the first sign of developing asthma. Therefore, management of these children is important. The first and the most important step of the management is the primary prevention against asthma with education of the patient and his caregivers. In acute exacerbation of wheezing the most preferred treatment should be $\beta_{2}$-agonists for both of the episodic and multi-trigger wheezing. Bronchodilators provide symptomatic relief in acute wheezy episodes but the evidence for oral steroid usage is contraversial for children. Parent initiated oral steroid courses cannot be recommended. Although maintenance treatment with low to moderate continuous inhaled corticosteroids (ICS) in pure episodic (viral) wheeze is ineffective, it has beneficial effects in multi-trigger wheezing. High dose ICS used intermittently are effective in children with both of the wheezing types, but this is associated with short term effects on growth and cannot be recommended as a routine. Leucotrien receptor antagonists (LTRA) might be recommended as continuous treatment for children with multi-trigger wheezing. Antihistamines, ketotifen and cromolyns do not have a role in management of wheezing in children. (Journal of Current Pediatrics 2012; 10: 98-102)

Key words: Exacerbation; wheezy child; treatment

\section{Giriş}

Hışıltı, alt havayollarında oluşan daralmaya bağlı olarak hızlı hava vibrasyonu ile meydana gelen yüksek titreşimli polifonik müzikal bir sestir (1). Hışıltılı çocuk, altta yatan bir başka neden olmamak kaydıyla hışıltısı bir aydan uzun süren ve/veya bir yıl içinde üç veya daha fazla tekrarlayan çocuktur.

'Hışıltılı çocuk' tanımı heterojen fenotipleri içerisinde barındıran, süresinde ve seyrinde farklılıklar içeren, patofizyolojisi birbirinden ayrı bir grup hastalı̆ı kapsayan kompleks bir durumdur (2). Süt çocukluğu dönemindeki 
hışıltılı hastalık ile daha sonra gelişebilecek astım arasındaki ilişki 50 yıldır araştııımaktadır. Erken çocukluk dönemindeki hışıltı fenotipleri ile astımın ortak risk faktörleri vardır. Ancak bu iki durumu birbirinden kesin olarak ayırt etmeye yarayacak yeterli veri ve kanıt henüz bulunmamaktadır.

Süt çocuklarında görülen hışıltı ile daha sonra gelişebilecek astım arasındaki ilişkinin immun sistemdeki maturasyon ve konjenital/kazanılmış havayolu değişikliklerinin bir sonucu olduğu yaygın bir kanıdır (2).

Süt çocukluğu döneminde hışıltılı solunumun sıklığı çeșitli yayınlarda \%4 ile \%32 arasında değişmektedir. Hışı|tılı çocukların \%90'nında 1 yaşın altında hışıtı atakları olurken bunların \%70'inde hışıltı 5 yaşında, \%90'ında ise okul çağında düzelir (3).

Hışıltılı çocukta tedavinin amacı semptomların kontrol altına alınması, akut alevlenmelerin önlenmesi, çocuğun günlük aktivitelerindeki bozulmasının önüne geçilmesi, akciğer fonksiyonlarının korunması, çocukta normal büyüme ve gelişmenin sağlanmasıdır.

Epizodik viral hışıltısı olan bir çocuğun tedavisi çocuğun akut hışıltı ataklarının sıklığına, astım prediktif indeksine göre astım açısından risk taşımasına göre kişisel olarak düzenlenmelidir (4).

Akut hışıtı ataklarının tedavisinde ilk basamak epizodik hışıtı ile bronşiyolitin ayrılmasıdır. Çünkü bronkodilatörler bronşiyolitte çok az ve kısa süreli fayda gösterirler (5). Akut hışıtı atağında en etkili ve ilk tercih edilmesi gereken ilaçlar $\beta_{2}$-agonistlerdir. Belirgin bronkodilatör etkileri vardır. Bronkokonstriktör ajanlara karşı koruyucudurlar ve genellikle iyi tolere edilirler. Süt çocuklarının çoğunda doğumdan itibaren fonksiyonel $\beta_{2}$-reseptörleri bulunur ve bu reseptörlerin uyarılması büyük çocuklarınkine benzer etki gösterir. Nadiren süt çocuklarında paradoks yanıtlar alınabilir bu nedenle bu yaş grubundaki çocuklar yakından takip edilmelidir $(4,6,7)$. Conner ve arkadaşlarının çalışmasında 3 yaşından küçük çocuklarda epizodik (viral) hışıltıda 1 hafta süreyle salbutamol kullanımı semptom skorlarında (8), Kraemer ve arkadaşlarının çalışmasında da akciğer fonksiyonları üzerinde belirgin düzelme yapmıștır (9). Fakat bazı çalışmalarda 2 yaş altındaki çocuklarda $\beta_{2^{-}}$ agonistlerin etkili olduğunun belirtilmesine rağmen akut ataklardaki yararı kesin olarak gösterilememiştir (10). Bu konudaki çelişkili sonuçlara rağmen birçok araştırma ve klavuz inhale $\beta 2$-agonistlerin küçük çocuklarda akut hışıltı ataklarında kullanılabileceğini önermektedir $(6,7,11,12)$. Çok ağır akut hışıltı ataklarında bir saatten uzun süren inhale tedaviye tanıt alınamaması durumunda intravenöz ß2-agonistler kullanılabilir. Beta-agonistler yüksek dozda kullanımda çarpıntı, huzursuzluk, başağrısı, kaslarda titreme, ajitasyon ve hipokalemiye neden olmaktadır bu nedenle küçük çocuklar yan etkiler açısından yakından takip edilmelidir (13). Oral ve intravenöz $\beta_{2}$-agonistler ciddi yan etkileri nedeniyle bu yaş grubunda önerilmemektedir.

Salmeterol ve formoterol okul öncesi çocuklarda astım tedavisinde kullanılmaktadır. Bronkoprotektif etkileri bulunmaktadır. Hışıltılı çocuklarda uzun etkili $\beta_{2}$ agonistlerin kullanımı konusunda çift-kör plasebo kontrollü çalışma bulunmamaktadır (11).

Okul öncesi çocuklarda hışıltı ataklarında 3-5 gün süre ile oral kortikosteroid kullanımı birçok pediatrist tarafından önerilmektedir (4). Bu uygulama için kanıt düzeyinde veri bulunmamaktadır. Yapılan bir çalışmada 6-35 ay arası çocuklarda 3 günlük oral steroid tedavisi ile hastalığın ağırlığı, hastanede yatış süresi ve semptom süresi azalmıştır (14). Başka bir çalışmada ise hışıtı nedeniyle hastaneye yatırılan 700 çocuk prednizolon veya plasebo ile randomize edilmiş, hafif-orta hışıltıda oral prednizolon plasebodan daha etkili bulunmamıştır (15). Fox ve arkadaşlarının çalıșmasında 3-14 ay arası 59 çocukta akut hışıltı atağı esnasında salbutamol etkili bulunurken tedaviye oral kortikosteroidlerin eklenmesi ek düzelme sağlamamıştır (16). Diğer taraftan, oral kortikosteroid kullanımı ile ilgili çalışmaların değerlendirildiği bir metaanalizde daha fazla sayıda çocuğun hastaneden 7 kat erken (4 saat içinde) taburcu olmasını, 1-3 ay içinde 5 kat az relaps geçirmesini sağladığı gösterilmiştir. Fakat, bu meta-analizde hışıltılı çocuklar ile ilgili çalışmalar ayrıca değerlendirilmemiştir (17).

Okul öncesi hışıltılı çocuklarda ailelerin 3-5 gün süreli oral kortikosteroid tedavisi başlamaları eskiden beri uygulanan bir tedavi şeklidir. Fakat bu uygulamanın yararını gösteren çalışma sonuçları tartışmalıdır. Bir beş yaş arası çocuklarda ailelerin 5 gün süre ile oral kortikosteroid kullanmalarının gündüz ve gece solunum semptom skorlarını düzeltici ve hastaneye yatış ihtiyacını azaltıcı etkisi gösterilememiştir. Bu nedenle intermittan hışı|tısı olan ve büyük çoğunluğu ileride düzelebilecek hasta grubuna aileleri tarafından yeterli klinik değerlendirme yapılmadan oral kortikosteroid verilmesi ek bir yarar getirmemekle birlikte ciddi yan etkilere de sebep olabilmektedir (18).

Antikolinerjik ilaçlardan ipratropium bromidin tek başına veya kısa etkili $\beta_{2}$-agonistler ile kombine edilerek kullanımının tedavi yanıtı, $\mathrm{O}_{2}$ saturasyonunda düzelme ve hastane yatışı üzerine ek yararı yoktur ancak bazı hastalarda $\beta_{2}$-agonistler ile kombine kullanımda 24 . saatte klinik skorlarda düzelme sağlamaktadır. Gösterilmiş önemli bir yan etkisi bulunmadığı için aileler genellikle tercih etmektedirler. Fakat 2 yaş altında hışıltı tedavisinde rutin kullanımının önerilmesi için yeterli düzeyde kanıt bulunmamaktadır (19). 
Epizodik (viral) hışıltıda düşük-orta doz inhale kortikosteroidler (IKKS) uzun dönemli tedavide semptomsuz gün sayısı, akut atak sıklı̆ı̆, ataklar arasındaki semptomlar açısından etkisiz bulunmuştur (20). Yüksek doz IKS (1600$3200 \mu \mathrm{g} /$ gün budesonid dozu) bazı yararlar sağlayabilirken, 10 günden kısa süreli $1,5 \mathrm{mg}$ flutikazon kullanımı da semptomlarda belirgin düzelme sağlamıştır. Aynı çalışmada, idame dozda budesonidin (400 $\mu \mathrm{g} /$ gün) yararı gösterilememiştir. Bu konudaki çalışmalar oldukça az sayıdadır ve küçük hasta gruplarını içermektedir. Fakat, yeni çalışmalarda epizodik hışıltının akut tedavisinde ancak yüksek dozlarda IKS kullanımı semptom skorunda ve oral steroid dozunda azalma yapıyor gibi görünmektedir (4). Cochrane meta-analizinde de yüksek doz IKS'lerin hafif epizodik viral hışıtı ataklarında yararlı olduğu, düşük doz IKS'lerin hışıtıdan koruyucu etkisinin bulunmadığı gösterilmiştir. Bu nedenle epizodik (viral) hışılıda IKS'ler yan etkiler göz önüne alınarak oldukça dikkatli verilmelidir (21).

Çoklu tetikleyicili hışılıda IKS'lerin yeri epizodik hışıltıya göre farklıdır. Çoklu tetikleyicili hışıltıda düşük-orta doz IKS kullanımı ile hışıtıların alevlenme sıklığında, havayolu aşırı duyarlılığında ve semptomlarda azalma ile akciğer fonksiyonlarında düzelme görülmüştür.

Hışıltılı çocuklarda IKS başlanan hastalar ortalama 3 ay sonra mutlaka değerlendirilmelidir. Yanıt yoksa tedavi kesilmeli diğer tanılar açısından hasta tekrar gözden geçirilmelidir. Bu durumda basamak arttırılmamalıdır. Çoklu tetikleyicili hışıltısı olan okul öncesi çocuklarda tedaviye yanıt iyi ise iki olasılık vardır. Birincisi, tedaviye bağlı yanıt, ikincisi hastalığın doğal seyrine bağlı düzelmedir. Inhale steroidden fayda gören hastaların tedavisi kesilmeli ve hasta yakından izlenmelidir. Tedavi kesildikten sonra semptomları başlayanlara tedavi tekrar başlanmalı ve klinik düzelme gerçekleşirse IKS'ler uzun süreli verilmelidir $(11,12)$.

Okul öncesi çoklu-tetikleyicili hışıltısı olan çocuklarda doz-yanıt ilişkisi bireysel farklılıklar göstermektedir. Sık atak geçiren, iki yaşından büyük, ailesinde astım öyküsü ve modifiye astım prediktif indeksi pozitif olan çocuklar IKS tedavisine çok daha iyi yanıt verirler $(11,12)$. Fakat, IKS'ler epizodik hışıltının persistan hışıltıya geçmesini önleyememekte yani hastalığın doğal seyrini etkilememekte ve uzun dönemde yarar sağlamamakta gibi görünmektedir. (12,22).

Hafif epizodik hışıtılı çocuklarda aralıklı veya devamlı IKS tedavisi verilmesinin etkilerini değerlendiren Cochrane meta-analizine göre aralıklı yüksek doz IKS'lerin üst solunum yolu enfeksiyonu başladığında verilmesi atakların ağırlığını ve oral steroid kullanımını azaltırken, hastaneye yatış süresi üzerinde etkili bulunmamıştır. Düşük doz IKS'lerin devamlı kullanılmasının ise hışוtıılı çocuklarda ek yararı gösterilememiştir (21). Ayrıca, aralıkı yüksek doz IKS uygulaması orta-ağır ağırııta sık epizodik hışıltı veya çoklu tetikleyicili hışıltılı çocuklarda etkili gözükmekle birlikte bu tedavilerin büyüme üzerine kısa süreli de olsa etkilerinin olması nedeniyle rutin kullanımı önerilmemelidir (11).

Idame tedavisinde lökotrien reseptör antagonistleri (LTRA) hafif persistan astım, egzersizle indüklenen astım ve 2-5 yaş arası çocuklarda viral enfeksiyonlarla tetiklenen epizodik astım alevlenmelerinde etkili olduğu bilinmektedir. Bisgaard ve arkadaşlarının epizodik hışıltılı çocuklarda yaptıkları bir çalışmada 549 çocukta 1 yıl boyunca devamlı montelukast kullanımı atak sıkığını \%32 azaltmıştır (23). Diğer taraftan, Knorr ve arkadaşlarının yaptıkları bir çalışmada 689 çocukta üç ay süresince montelukast kullanımı çoklu tetikleyicili hışıltı ataklarını \%30 oranında azaltmıştır (24). Bir başka çalışmada da 220 çocukta aralıkı montelukast kullanımı randevusuz doktor ziyaretini \%30 oranında azaltırken, hastaneye yatış, atak süresi, salbutamol ve sistemik kortikosteroid kullanımını etkilememiştir. Sonuçta, lökotrien reseptör antagonistlerinin hem epizodik hemde çoklu tetikleyicili hışıltıda yararı gösterilmiştir fakat etkinlikleri IKS'lerden daha az bulunmuştur (25).

Uzun süreli ilaç kullanımının zamanla ilaca uyumu azalttığı bilinen bir gerçektir. Bu nedenle aralıklı ilaç kullanımı bazı hastalar ve doktorlar tarafından tercih edilmektedir. Bu amaçla orta-ağır hışıltı tedavisinde aralıklı IKS veya LTRA kullanımının etkinliği açısından yapılan bir çalışmada 12-59 aylık ikiden fazla hışıltı atağı geçiren 238 çocukta, aralıklı ilaç kullanımı ile sadece akut solunum yolu semptomlarında kısmi azalma görülürken hışıltı sıklığında bir azalma gösterilememiştir. Astım prediktif indeksi pozitif olan çocuklarda IKS ile LTRA'nın etkinliği eşit bulunmuştur (26).

Sodyum kromoglikat ve nedokromil sodyum en iyi bilinen kromolin türü ilaçlar, teofilin ve aminofilin de ksantin türü ilaçlardır. Kromolin, ksantin ve antihistaminiklerin okul öncesi çocuklarda hışıltı tedavisinde yararı gösterilememiştir $(6,7,11,12)$.

Yapılan birçok çalışmaya rağmen günümüzde hışılılı çocuk tedavisi ile ilgili kesin bir fikir birliğinin olmaması çalışmalarda hasta seçim kriterleri, yaş aralıkları, tedavi dozları arasındaki farklııılar nedeniyle sonuçların çelişkili bulunmasına bağlıdır (4).

Tedavi raporları özetlenecek olursa, halen tartışmalı olsa da akut atakta ilk tercih edilecek ilaçlar aralıklı ß2agonistler olmalıdır. Akut hışıtı atağında inhale kısa etkili $\beta 2$-agonistler kullanılması önerilirken, infantlarda paradoks etkiler görülebileceği için dikkatli olunmalıdır. Oral veya IV yol ile kısa etkili $\beta_{2}$-agonist kullanımı ağır 
durumlar dışında tercih edilmemelidir. Ağır hışıltı ataklarında kısa etkili $\beta_{2}$-agonistlere ipratropium bromid eklenebilir. Hastaneye yatmasını gerektirecek kadar ağır olgularda oral kortikosteroidler denenebilir. Fakat ailelerin oral kortikosteroid tedavisi başlaması önerilmemelidir. Ataklarda yüksek doz IKS'ler kısmen etkili gibi görünse de yüksek maliyet ve yeterli düzeyde kanıt olmaması nedeni ile önerilmemektedir $(7,11,12)$.

Epizodik hışıtının idame tedavisi çocuğun akut hışıltı ataklarının sıklığına, astım prediktif indeksine göre astım açısından risk taşımasına göre kişisel olarak düzenlenmelidir. Epizodik hışıltıda ilk tercih ataklar esnasında kullanılmak üzere $\beta_{2}$-agonistler olmalıdır (kanıt düzeyi A). Bir mevsimde üçten fazla atak geçirenlere koruyucu tedavi başlanmalıdır (kanıt düzeyi D). Bu hastalara montelukast önerilebilirken, ailede astım hikayesi varsa IKS'ler denenebilir $(11,12)$.

Çoklu tetikleyicili hışıltının idame tedavisinde ise standart doz IKS'lerin (400 $\mu \mathrm{g} / \mathrm{gün}$ 'e kadar budesonid) verilmesi uygun bir yaklaşım gibi görünmektedir. Bir yaşın altında IKS'ler önerilmezken, 1-2 yaş arasına semptomlar ağırsa ve tedaviye iyi yanıt veriyorsa verilmelidir. Tedavi kullanıldığı sürede etkindir, ara verilmesi durumunda etkisi görülmez. Tedavi süresince boy uzaması takip edilmelidir. Hışıltı kontrol altına alınıncaya kadar tedaviye devam edilmeli, semptomların düzelip düzelmemesini görmek için bir süre tedaviye ara verilmeli gerekirse tekrar başlanmalıdır. Yanıt vermiyorsa doz arttırılmamalı diğer olası hastalıklar gözden geçirilmeli ve hasta uzmana yönlendirilmelidir. Kromolin, ksantin, ketotifen ve immunoterapi bu hasta grubuna önerilmemektedir. Tedavilerin hastalığın doğal seyri üzerine etkisi olmadığı gibi astım gelişimini önleme etkisi de yoktur $(4,11)$.

Atakların önlenmesinde önemli yaklaşım hastanın ve ailesinin eğitimidir $(6,12)$. Küçük çocuklarda gereksiz antibiyotik kullanımı engellenmeli, çevresel önlemler çok yönlü alınmalı, ataklar arasında normal ve atak esnasında hospitalizasyon gereksinimi olan çocuklar astım açısından dikkatli değerlendirilmelidir. Tedavi seçeneği ne olursa olsun multidisipliner yaklaşım ile hastalar ileride gelişebilecek astım veya düşük akciğer fonksiyonları açısından yakından takip edilmelidir.

\section{Kaynaklar}

1. Brand PL, Baraldi $\mathrm{E}$, Bisgaard $\mathrm{H}$, Boner $\mathrm{AL}$, Castro-Rodriguez JA, Custovic A, et al. Definition, assessment and treatment of wheezing disorders in preschool children: an evidence-based approach. Eur Respir J 2008;32:1096-110.

2. Castro-Rodriguez JA, Garcia-Marcos L. Wheezing and asthma in childhood: an epidemiology approach. Allergol Immunopathol (Madr) 2008;36:280-90.
3. Strachan D, Sibbald B, Weiland S, Aït-Khaled N, Anabwani G, Anderson HR, et al. Worldwide variations in prevalence of symptoms of allergic rhinoconjunctivitis in children: the International Study of Asthma and Allergies in Childhood (ISAAC). Pediatr Allergy Immunol 1997;8:161-76.

4. Bhatt JM, Smyth AR. The management of pre-school wheeze. Paediatr Respir Rev 2011;12:70-7.

5. Gadomski AM, Bhasale AL. Bronchodilators for bronchiolitis. Cochrane Database of Syst Rev 2006;3:CD001266.

6. National Institues of Health Global Strategy for Asthma Management and Prevention. GINA NIH Publication 2009.

7. Bacharier LB, Boner A, Carlsen KH, Eigenmann PA, Frischer $T$, Götz M, et al. Diagnosis and treatment of asthma in childhood: a PRACTALL consensus report. Allergy 2008;63:5-34.

8. Conner WT, Dolovich MB, Frame RA, Newhouse MT. Reliable salbutamol administration in 6- to 36-month-old children by means of a metered dose inhaler and Aerochamber with mask. Pediatr Pulmonol 1989;6:263-7.

9. Kraemer R, Frey U, Sommer CW, Russi E. Short-term effect of albuterol, delivered via a new auxiliary device, in wheezy infants. Am Rev Respir Dis 1991;144:347-51.

10. Chavasse R, Seddon P, Bara A, McKean M. Short acting beta agonists for recurrent wheeze in children under 2 years of age . Cochrane Database Syst Rev 2002;3: CD002873.

11. Brand PL, Baraldi E, Bisgaard H, Boner AL, Castro-Rodriguez $J A$, Custovic $A$, et al. Definition, assessment and treatment of wheezing disorders in preschool children: an evidence-based approach. Eur Respir J 2008;32:1096-110.

12. Taussig LM, Wright AL, Morgan WJ, Harrison HR, Ray CG. The Tucson Children's Respiratory Study.l. Design and implementation of a prospective study of acute and chronic respiratory illness in children. Am J Epidemiol 1989;129:1219-31.

13. Skoner DP, Greos LS, Kim KT, Roach JM, Parsey M, Baumgartner RA. Evaluation of the safety and efficacy of levalbuterol in 2-5-year-old patients with asthma. Pediatr Pulmonol 2005;40:477-86.

14. Csonka $P$, Kaila $M$, Laippala $P$, Iso-Mustajärvi $M$, Vesikari $T$, Ashorn P. Oral prednisolone in the acute management of children age 6 to 35 months with viral respiratory infectioninduced lower airway disease: a randomized, placebocontrolled trial. J Pediatr 2003;143:725-30.

15. Panickar J, Lakhanpaul M, Lambert PC, Kenia P, Stephenson T, Smyth A, Grigg J. Oral prednisolone for preschool children with acute virus-induced wheezing. $N$ Engl J Med 2009;360:329-38.

16. Fox GF, Marsh MJ, Milner AD. Treatment of recurrent acute wheezing episodes in infancy with oral salbutamol and prednisolone. Eur J Pediatr 1996;155:512-6.

17. Smith M, Iqbal S, Elliott TM, Everard M, Rowe BH. Corticosteroids for hospitalised children with acute asthma. Cochrane Database Syst Rev 2003;2:CD002886.

18. Vuillermin PJ, Robertson CF, South M. Parent-initiated oral corticosteroid therapy for intermittent wheezing illnesses in children: systematic review. J Paediatr Child Health 2007;43:438-42.

19. Everard ML, Bara A, Kurian M, Elliott TM, Ducharme F, Mayowe V. Anticholinergic drugs for wheeze in children under the age of two years. Cochrane Database Syst Rev 2005;3:CD001279. 
20. Wilson N, Sloper K, Silverman M. Effect of continuous treatment with topical corticosteroid on episodic viral wheeze in preschool children. Arch Dis Child 1995;72:317-20.

21. McKean M, Ducharme F. Inhaled steroids for episodic viral wheeze of childhood. Cochrane Database Syst Rev 2000;2:CD001107.

22. Bisgaard $\mathrm{H}$, Hermansen MN, Loland L, Halkjaer LB, Buchvald F. Intermittent inhaled corticosteroids in infants with episodic wheezing. N Engl J Med 2006;354:1998-2005.

23. Bisgaard H, Zielen S, Garcia-Garcia ML, Johnston SL, Gilles L, Menten J, et al. Montelukast reduces asthma exacerbations in 2- to 5-year-old children with intermittent asthma. Am J Respir Crit Care Med 2005;171:315-22.
24. Knorr B, Franchi LM, Bisgaard H, Vermeulen JH, LeSouef $P$, Santanello N, et al. Montelukast, a leukotriene receptor antagonist, for the treatment of persistent asthma in children aged 2 to 5 years. Pediatrics 2001;108:E48.

25. Robertson CF, Price D, Henry R, Mellis C, Glasgow N, Fitzgerald $D$, et al. Short-course montelukast for intermittent asthma in children: a randomized controlled trial. Am J Respir Crit Care Med 2007;175:323-9.

26. Bacharier LB, Phillips BR, Zeiger RS, Szefler SJ, Martinez FD, Lemanske RF Jr, et Episodic use of an inhaled corticosteroid or leukotriene receptor antagonist in preschool children with moderate-to-severe intermittent wheezing. J Allergy Clin Immunol 2008;122:1127-35. 